\title{
Climate Change and Variability in Semiarid Palapye, Eastern Botswana: An Assessment from Smallholder Farmers' Perspective $\mathscr{O}$
}

\author{
FELICIA O. AKINYEMI \\ Earth and Environmental Science Department, College of Sciences, Botswana International \\ University of Science and Technology, Palapye, Botswana
}

(Manuscript received 31 March 2016, in final form 3 February 2017)

\begin{abstract}
Smallholder farmers are particularly vulnerable to the effects of climate change and variability in semiarid contexts. Despite the limited adaptation options often used and the largely subsistence agriculture practiced, studies have shown that smallholders have accumulated local knowledge about changes in climatic conditions. Farmers with field experience and an extensive stay in three sites in Palapye, eastern Botswana, were interviewed. This study related farmers' perceptions of changes in climate with results from analysis of climate data. Major changes perceived are a reduction in rainfall amount, rising temperature, and increasing frequency of drought conditions. Perceived reduction in rainfall amount is confirmed by analysis results as variability in rainfall amount is high throughout the series. Rainfall was poorly distributed and below average at the beginning of the cropping seasons for four years between 2013 and 2017. For 1990, 2003, and 2012, the standardized precipitation index (SPI) was -1.77 (severe drought), -1.37 (moderate drought), and -2.32 (extreme drought), respectively. To minimize impacts on crop production, farmers simultaneously planted different crops based on the perception that climatic impacts on different crops vary and favored crops perceived as drought resistant. Livestock farmers supplemented with livestock feeds, reduced herd size, and moved livestock to areas with better forage. Off-farm incomes from selling products harvested from the wild are important to farmers as a coping strategy, particularly when rain fails. Some female farmers brewed and sold alcohol made locally from sorghum. That local knowledge and perceptions exist and are used by smallholder farmers to adapt to climate change and variability is suggested. Engaging with local knowledge systems is an imperative for climate change policy making.
\end{abstract}

\section{Introduction}

That climate change impacts agriculture is evident $(\mathrm{Li}$ et al. 2009; Lobell et al. 2011; Burney and Ramanathan 2014; Chavez et al. 2015; Torquebiau et al. 2016; Villoria et al. 2016). From local to global scales, studies have examined climate change impacts on fisheries (Lam et al. 2012), crop productivity (Wheeler and von Braun 2013), and livestock (Thornton et al. 2015), among others. Links are being sought between variation in climate and crop yields (Ayanlade et al. 2009; Osborne and Wheeler 2013; Deepak et al. 2015). Although results vary and uncertainties still abound in most studies

\footnotetext{
Supplemental information related to this paper is available at the Journals Online website: http://dx.doi.org/10.1175/ WCAS-D-16-0040.s1.
}

Corresponding author e-mail: Felicia O. Akinyemi, felicia.akinyemi@ gmail.com
(Chavez et al. 2015), as multiple human and climatic factors are at play and models differ in their constructs, assumptions, and time frames, the consensus is that there is some risk everywhere in Africa for agriculture to be negatively impacted by climate change (Li et al. 2009; Müller et al. 2011). Some studies on climate change impacts with a focus on agriculture in Africa are Kurukulasuriya et al. (2006), Di Falco and Veronesi (2013), Dube et al. (2016), and Rippke et al. (2016).

Countries with predominantly agriculture-based economies in sub-Saharan Africa, where funding for adaptation mechanisms is scarce, having warmer baseline climates, and exposure to extreme climatic events, are more vulnerable to climate change than others (Parry et al. 2001; Soussana et al. 2010). Van Wesenbeeck et al. (2016) characterized vulnerability to changes in climate among population groups in East and West Africa according to their socioeconomic and biophysical characteristics. Local communities in most parts of Africa are still largely food insecure because of dependence on 
rain-fed, subsistence agriculture, which leaves them highly vulnerable to climate change. Impacts can be very severe on smallholder farmers when rainfall fails during a cropping season. This category of farmers constitutes the bulk of the rural population. Rural dwellers employed in agriculture or partly dependent on agricultural activities could be as high as $70 \%$ or more [Parson (1984); Ministry of Finance and Development Planning (MFDP; MFDP 2010)].

Negative impacts on agriculture due to climate change exacerbate the challenges already being faced in ensuring food security and poverty reduction in sub-Saharan Africa. Linked to food insecurity is malnutrition, which is recognized as an adverse health impact of climate change (Phalkey et al. 2015). Moreover, linkages between climate change, agriculture, and poverty are already established in the literature (FAO 2006; Thomas et al. 2008; Hertel and Rosch 2010). Agriculture has direct and indirect impacts on poverty and agricultural growth is a key engine of economic development (Bresciani and Valdés 2007; DFID 2008).

African smallholder farmers face a variety of challenges, leaving them vulnerable to climate change despite their efforts to adapt (Osbahr et al. 2010). Arable agriculture in semiarid environments is predominantly a high-risk, rain-fed, and low-input system (MFDP 2010). With farm sizes often less than 1 ha, traditional farm implements are still in use, as poverty prevents smallholders from adopting technology. Cultivating relatively poor soils that are depleted of nutrients because of continuous use and very low fertilizer input makes crop productivity typically low in Africa (Drechsel et al. 2001).

Heavy reliance on rainfall and the limited opportunities for economic diversification leave prospects for development in sub-Saharan Africa closely linked with climate (Di Falco 2014). Although findings from studies are mixed, the majority of studies suggest that farmers' knowledge of the vagaries of climate is valid and that local knowledge is an invaluable input to effective adaptation in the twenty-first century (Thomas et al. 2007; Mertz et al. 2009; Ogalleh et al. 2012). The validity of local knowledge complementing scientific analysis of climate data is not entirely in doubt, as studies have found it is mutually beneficial to scientists and rural communities. It provides insights into the adaptive capacity of communities and repositories of locally held environmental knowledge passed down for generations (Eicken et al. 2014; Jones et al. 2015).

This article examines existing local knowledge among farmers, including their level of awareness, perceptions, and strategies adopted to cope with climate change and variability. How aware are smallholders about climate change? Have they perceived long-term changes in rainfall and temperature? How have they adapted to whatever climate change they believe has occurred? The definition of local knowledge by Ogalleh et al. (2012, p. 3304), is adopted "as a cumulative body of knowledge on weather and climate, developed and applied by smallholders, which shows how this knowledge is used to shape and interact with agricultural practices to enhance smallholders' adaptive capacity towards climate variability." The term "local" connotes knowledge that is sourced from among farmers in the same area, as they are directly affected by the local impacts of climate change. According to Dube et al. (2016), adaptation must be suited to local conditions, which vary widely across Africa.

Perception is important, as it majorly determines beliefs that are upheld, which will ultimately contribute to farmers' behavior, such as the decision to adopt some coping strategies and/or adapt (Ogalleh et al. 2012; Mengistie et al. 2015). Adaptation to climate change requires that farmers first notice alterations before measures can be identified and successfully implemented (Hassan and Nhemachena 2008). Investigating farmer behavior is imperative in order to inform adaptation to environmental change and transitions to sustainable agriculture (Feola et al. 2015).

\section{Background}

Relatively unknown at independence in 1966, Botswana is currently a middle-income nation. Sustainable growth and diversification of the economy is a major policy drive of the government (Vision 2016 Council 2010). Contributing $2.6 \%$ of Gross Domestic Product, agriculture is identified as having great potential to create employment in rural areas (MFDP 2010; Honde and Abraha 2015).

The study area is located in the Central District of Botswana and comprises Palapye and other surrounding villages (Fig. 1). This district plays a major economic role, as most mines for diamond, coal, copper, nickel and sodium carbonate (soda ash) are located there. Palapye is ideal for this kind of study because of its semiarid climate with an average annual rainfall of $351 \mathrm{~mm}$ between 1960 and 2015. There is the orographic effect on rainfall distribution, as Palapye is situated between the Matepilepi Hills to the northwest and the Tswapong Hills to the southeast. There are 7554 traditional agricultural holdings (both crop and pastoral) in Palapye, giving it a share of $6 \%$ of all agricultural holdings in Botswana (Statistics Botswana 2015a). Strategically located between Gaborone (Botswana's capital) and Francistown, Palapye is experiencing social and economic transformations, with 


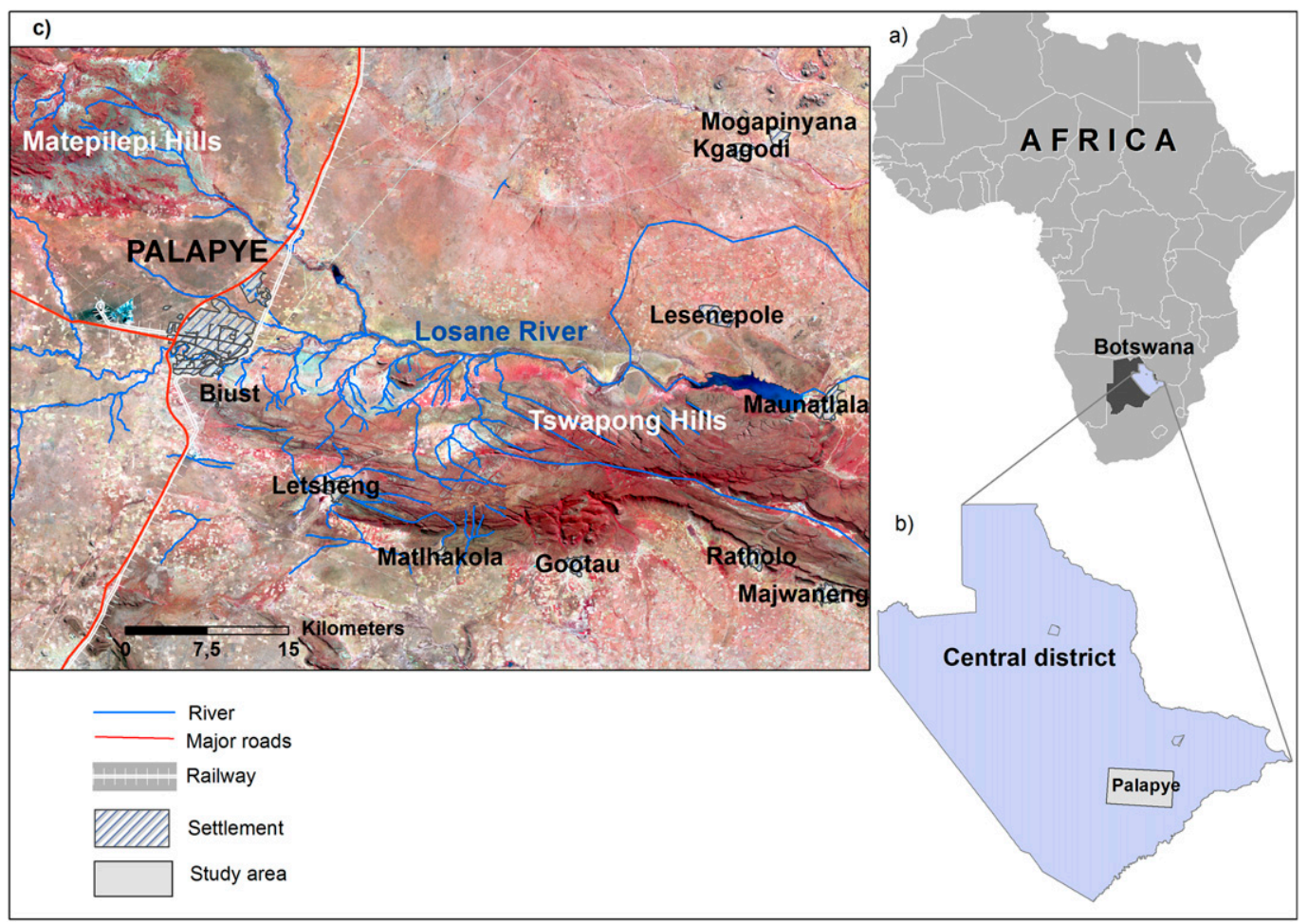

FIG. 1. (a) Botswana in Africa. (b) Study area in the Central District, eastern Botswana. (c) Palapye as depicted on a Landsat 8 satellite image with farmlands and bare lands appearing as white and light green patches.

41086 inhabitants as of 2011, up from 26293 in 2001 (Statistics Botswana 2015b). As the population grows, so does the demand for land, energy, food, and water. Consequently, agricultural lands are being converted for residential, commercial, and infrastructural purposes (Mashame and Akinyemi 2016).

\section{Methodology}

The larger study from which this article emanated is interdisciplinary, employing methods from anthropology, geospatial, environmental, and natural sciences (Table 1). This specific research combines the use of qualitative and quantitative data from methods including questionnaire surveys, semistructured interviews, participant observation, use of global positioning systems (GPS), and instrumental climate data.

Participation in farmers' meetings created opportunities for discussion and provided insider views of how climate-related challenges facing farmers are tackled administratively. Kgotla (village meetings) were also organized for awareness creation and to solicit support to conduct the survey. The Kgosi (chief) oversees such meetings as the head of the Tribal Authority, which is a recognized administrative arm of government. Two stakeholder workshops were also organized and issues related to climate change, variability, and land degradation in Palapye were discussed. Combining data from these methods provided insight about farmers' perceptions of changing climatic conditions in Palapye. According to Lorenzoni et al. (2007), the complementarities of mixed methods allow for more in-depth insight and triangulation of findings.

\section{a. Sample design}

The survey was conducted from 3 March to 10 April 2015 using stratified random sampling, whereby 137 farmers were selected according to the agriculture types [cultivators, mixed crop-livestock farmers, pastoralists, horticulturists, and apiculturists (beekeepers)]. Farmers were further subdivided according to their location into east, west, and Lecheng for geographic representativeness, with 28,41 , and 71 farmers surveyed, respectively, from these sites.

Criteria employed to select farmers are the duration of settling in Palapye ( $\geq 16 \mathrm{yr}$ ) and years of farming experience as the main occupation ( $\geq 16 \mathrm{yr}$ ). These account for the varying years of settling and farming experience among farmers in the study area. As the recall of perceived changes in climate extends to the last 10 years, farmers having experience beyond this time frame were considered most suitable to provide relevant information. These 
TABLE 1. Methods employed for qualitative and quantitative data collection in the larger study.

\begin{tabular}{|c|c|c|c|}
\hline Method & Description & Selection criteria & Remark \\
\hline Questionnaire survey & Farmers & $\begin{array}{l}\text { Duration of stay in Palapye and } \\
\text { years of farming experience }\end{array}$ & No. of farmers: 137 \\
\hline $\begin{array}{l}\text { Semistructured } \\
\text { interviews }\end{array}$ & $\begin{array}{l}\text { Key informants and } \\
\text { farmers during farm visit }\end{array}$ & $\begin{array}{l}\text { Key informants were selected } \\
\text { from relevant government } \\
\text { and tribal authorities }\end{array}$ & No. of key informants: 25 \\
\hline Field observation & $\begin{array}{l}\text { Farm visit, collection of location } \\
\text { data using GPS, and informal } \\
\text { discussion with farmers for } \\
\text { clarity of responses }\end{array}$ & & $\begin{array}{l}\text { Each farmer's farm } \\
\text { was visited }\end{array}$ \\
\hline Participant observation & $\begin{array}{l}\text { We participated in the Kgotla } \\
\text { (village meeting) and farmers' } \\
\text { committee meetings }\end{array}$ & & $\begin{array}{l}\text { We participated in six } \\
\text { such meetings }\end{array}$ \\
\hline $\begin{array}{l}\text { Stakeholder workshops } \\
\text { with an average } \\
\text { attendance of } 50 \\
\text { participants }\end{array}$ & $\begin{array}{l}\text { Presented study objectives, } \\
\text { disseminated and discussed } \\
\text { research findings, and } \\
\text { received feedback from } \\
\text { stakeholders }\end{array}$ & $\begin{array}{l}\text { Participants were drawn from } \\
\text { government departments, industry } \\
\text { managers, media, high school } \\
\text { teachers, and farmers }\end{array}$ & $\begin{array}{l}\text { Two such workshops } \\
\text { were organized }\end{array}$ \\
\hline \multirow[t]{3}{*}{$\begin{array}{l}\text { Land degradation } \\
\text { assessment and } \\
\text { mapping }\end{array}$} & $\begin{array}{l}\text { Calculated land degradation } \\
\text { index for Palapye }\end{array}$ & $\begin{array}{l}\text { The composite land degradation } \\
\text { index (CLDI) was used }\end{array}$ & $\begin{array}{l}\text { Produced maps of land } \\
\text { degradation status and the } \\
\text { dominant degradation types }\end{array}$ \\
\hline & $\begin{array}{l}\text { Field sampling and laboratory } \\
\text { analysis of soil and water }\end{array}$ & $\begin{array}{l}42 \text { sampling sites were selected } \\
\text { based on soil unit, land use, } \\
\text { proximal distance, and } \\
\text { accessibility }\end{array}$ & $\begin{array}{l}\text { In situ data were collected } \\
\text { through field observation } \\
\text { and measurements and } \\
\text { analyzed in the laboratory }\end{array}$ \\
\hline & $\begin{array}{l}\text { Earth observation and } \\
\text { Geographic Information } \\
\text { System (GIS) }\end{array}$ & $\begin{array}{l}\text { Remote sensing satellite images } \\
\text { between } 1986 \text { and } 2014 \text { were } \\
\text { selected based on availability, } \\
\text { season, and percentage } \\
\text { cloud cover }\end{array}$ & $\begin{array}{l}\text { Image data interpretation, } \\
\text { classification, and CLDI } \\
\text { values were integrated in } \\
\text { a GIS }\end{array}$ \\
\hline
\end{tabular}

criteria were identified as having importance in the ability of Kenyan farmers to recall changes in climatic conditions (Ogalleh et al. 2012). The exception was for 12 smallholders who had settled in Palapye for more than 26 years but had less than 16 years of farming experience. Three decades of settling in Palapye with some years of farming experience, suffice for easy climate-related recall.

Purposive sampling was used in selecting relevant organizations and government departments for interview. From among farmer committee representatives, village development committee members, and officials of government departments dealing with agriculture, environment, rangeland management, spatial planning, land administration, and tribal issues, twentyfive persons were interviewed.

\section{b. Data collection}

Relating to the aim of examining smallholder perceptions of climate change and variability, 14 closed and/or open-ended questions were presented to farmers. These dealt with awareness of climate change and variability, notice of long-term changes in rainfall and temperature since initial settling in Palapye, climatic constraints to crop and livestock production, and strategies adopted. The instrument was pretested to address problems associated with the interpretation of questions, the ease with which questions were understood, and the average time required to fully answer the questions. The questionnaires containing structured and open-ended questions were administered to farmers during face-to-face sessions. This meant that each question was read out by the interviewer and answers were recorded. Although this technique of organizing face-to-face meetings with the farmers is costly and time consuming, it ensured that questions were well understood and none was left unanswered (Akinyemi 2011). Semistructured interviews were conducted with staff of relevant government and tribal authorities. Some responses from farmers were verified through these interviews, and we gained an additional perspective on issues from a policy standpoint.

Secondary data about types of farmers were collected from the farmer committee. Historical monthly rainfall data (1989-2015) in millimeters for the Palapye police weather station, produced by the Botswana Department of Meteorological Services (BDMS) were also used. Monthly precipitation anomaly images were extracted for the Central 
District of Botswana based on the European Centre for Medium-Range Weather Forecasts (ECMWF) model. These images were downloaded from the FAO Global Information and Early Warning System on Food and Agriculture (GIEWS) website (http:// www.fao.org/giews/earthobservation/country/index. jsp? $\operatorname{code}=$ BWA\#).

\section{c. Data analysis}

Descriptive statistics from the analysis of data items are presented using frequencies and percentages. Smallholders' perceptions of drought conditions, often referred to as lack or low rainfall, were compared to the drought analysis results. The drought index used is the standardized precipitation index (SPI) with categories ranging from extremely wet $(\geq 2.00)$ to extreme drought $(\leq-2.00)$. SPI was chosen because it uses only rainfall in its computation. Rainfall anomaly was also calculated by subtracting that month's long-term average from the monthly rainfall data. The annual anomalies were calculated as the average of the monthly anomalies for each year. The coefficient of variation $(\mathrm{CV})$ was used to assess variation in interannual rainfall amounts for the entire series.

\section{Results and discussion}

This study relates farmers' perception of changes in climatic conditions with results of analysis using available rainfall data. Banerjee (2015) noted that farmers' perceptions are an important input to policy in order to tackle climate-related challenges faced by farmers.

\section{a. Sociodemographic characteristics of farmers}

Studies have found that personal characteristics, such as education, gender, age, and beliefs influence peoples' perceptions of climate change (Gbetibouo 2009; Whitmarsh 2011). Lee et al. (2015) found the level of education to be the single strongest predictor of climate change awareness based on survey data from 119 countries. Relating to the education levels of farmers surveyed for this research, $28 \%$ of farmers interviewed have no schooling at all and $52 \%$ have a primary education (equivalent to Grades $1-7$ ), whereas $20 \%$ have secondary school education (equivalent to Grades 8-12) and/or tertiary. In terms of age, $39 \%$ of farmers are within the 50-64 age bracket, $34 \%$ are 65 years old or older, $18 \%$ are between 35 and 49 years old, and only $6 \%$ are 34 years old or younger. Regarding their gender, $62 \%$ and $38 \%$ are female and male, respectively. Gbetibouo (2009) found that in the Limpopo basin, South Africa, uneducated farmers are more likely to perceive long-term changes in rainfall, and, with

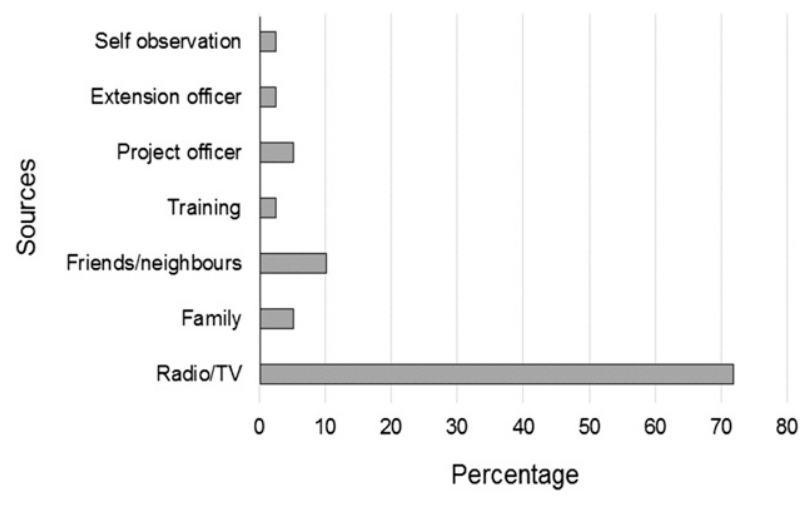

FIG. 2. Sources of information about climate change among smallholders.

experience, farmers are more likely to perceive a change in temperature. Among African farmers surveyed in 11 countries, those with the greatest experience of farming are more likely to notice climate change, and education is the main determinant in using adaptation strategies (Maddison 2007).

\section{b. Awareness of climate change and variability among smallholders}

A lack of knowledge about climate change may contribute to a sense of uncertainty, resulting in inaction to adapt (Lorenzoni et al. 2007). Concerning awareness about climate change and variability, $75 \%$ and $66 \%$ of female and male farmers, respectively, have heard of it and are aware. Figure 2 shows radio and/or television as the main sources of information to smallholders $(72 \%)$. This finding indicates the important role of media in communicating about climate change to smallholders in this context. Boykoff et al. (2015) noted that the majority of people rely solely on media representations (i.e., television, newspapers, radio, and social media) when relating to scientific findings of climate.

\section{c. Local knowledge and perceptions of climate change and variability}

Some studies examining how farmers perceive climate change are Maddison (2007), Gbetibouo (2009), Mattee et al. (2014), and Banerjee (2015). Asked how the climate is currently and how it was when they first settled in Palapye, $91 \%$ percent of smallholders perceived the initial climate when they settled as good, whereas only $5 \%$ and $4 \%$ said it was bad and very bad, respectively (Fig. 3). Decades after settling, the current climate is perceived as very bad by $81 \%$, and bad by $17 \%$, whereas only $2 \%$ of the farmers said it is good. Responses from the three sublocations are shown in the appendix. The fact that none of these experienced farmers say they do 
a)
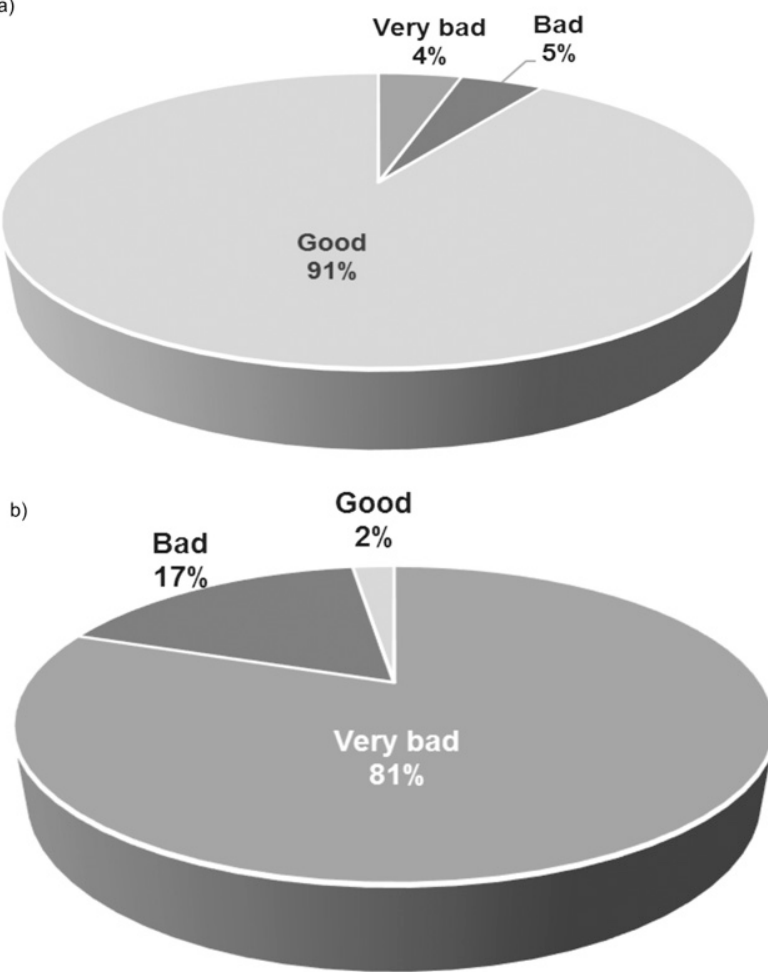

FIG. 3. Perceptions of climate: (a) initial climate at settling and (b) current climate.

not know whether changes occurred in the climate is added evidence that local people have some knowledge and perception of climate variability and change.

Asked what has changed in the climate since they settled in Palapye, reduction in rainfall amount and rising temperature, referred to as scorching heat from the sun, and increase in the occurrence of drought conditions were mentioned (Table 2). These perceived changes in climate indicators are in line with the research of Van Wilgen et al. (2015), who found changes in rainfall patterns and rising temperatures in 19 national parks in neighboring South Africa.

Presented a list of climatic indicators, perceived changes in current climate were compared to the previous year (last 12 months) for the short-term period and 10 years ago for the long-term period (Table 3). Responses regarding how these indicators have changed are further discussed in sections $4 \mathrm{c}(1)(\mathrm{i}), 4 \mathrm{c}(1)$ (ii), and $4 \mathrm{c}(1)$ (iii) under rainfall, temperature and drought conditions, respectively.

\section{CHANGES IN RAINFALL AND TEMPERATURE}

In Africa, rainfall pattern is an important climatic factor for agricultural production. Recent reviews of historical events also suggest the need to take cognizance of agriculture's sensitivity to increasing temperatures
TABLE 2. Responses to what has changed in the climate since you came here?

\begin{tabular}{llrrr}
\hline \hline & & \multicolumn{2}{c}{$\begin{array}{c}\text { Palapye sublocations } \\
(\%)\end{array}$} \\
\cline { 3 - 5 } \multicolumn{1}{c}{ Indicators } & \multicolumn{1}{c}{ Perception } & West & East & Lecheng \\
\hline Rainfall & Reduced & 52 & 32 & 55 \\
Heat & Increased & 25 & 21 & 13 \\
Drought conditions & Increasing frequency & 10 & 41 & 19 \\
Hunger & Increasing frequency & 10 & 3 & 9 \\
Death of livestock & Increasing frequency & 2 & 3 & 4 \\
\hline
\end{tabular}

(Müller et al. 2011). Chipanshi et al. (2003) noted that rainfall variability is an important limiting factor to dryland farming in Botswana. Parida and Moalafhi (2008) found that annual rainfall declined after 1981 based on data from 1961 to 2003 at 11 synoptic stations in Botswana. In addition to intra- and interannual rainfall variability, the nature and occurrence of extreme events, such as droughts and floods, are also important to the agricultural sector.

In the short term, all farmers perceived rainfall amounts and temperatures to have changed. Their perceptions of changes in climatic conditions for the short and long term were compared to check for consistency.

\section{(i) Rainfall}

For the long term, the majority (92\%) of smallholders viewed rainfall amount to have decreased in Palapye. Their perceptions of reduced rainfall amount were compared to analysis of rainfall data. Figure 4 shows the interannual rainfall variability over Palapye between June 1989 and February 2015 with a coefficient of variation of $47 \%$. CV above $30 \%$ indicates high variability in rainfall amounts and distributional patterns (Kisaka et al. 2015). Thus, annual rainfall amount fluctuated, with the year 2000 having the highest amount in the entire series and a trend generally toward an increase in rainfall.

The need to better understand farmers' perceptions of a reduction in rainfall amount and rainfall timing necessitated further examination during the cropping seasons. The cropping season that coincides with the rainy summer months extends from September to April, with peaks in November to February (see Fig. 5a). In Barolong, Southern Botswana, Adelabu et al. (2011) found that the onset of rain shifted by at least 40 days during the 2008/09 cropping season when compared with the baseline 1960/61 onset dates.

In the absence of complete observed growing season rainfall data, the ECMWF precipitation anomaly estimates for 2013-17 were used. Figure 5b compares the following cropping seasons: 2013/14, 2014/15, 2015/16, 
TABLE 3. Smallholder farmers' perceptions of climate variability and change.

\begin{tabular}{|c|c|c|c|c|c|}
\hline \multirow[b]{3}{*}{ Indicators } & \multicolumn{2}{|c|}{ Perception } & \multirow{2}{*}{\multicolumn{3}{|c|}{ Palapye sublocations (\%) }} \\
\hline & \multirow{2}{*}{$\begin{array}{l}\text { Did this change compared } \\
\text { to last year (12 months)? }\end{array}$} & \multirow{2}{*}{$\begin{array}{l}\text { Did this change compared } \\
\text { to the situation } 10 \mathrm{yr} \text { ago? }\end{array}$} & & & \\
\hline & & & West & East & Lecheng \\
\hline \multirow[t]{3}{*}{ Rainfall amount } & Yes & & 100 & 100 & 100 \\
\hline & & Increased & 8 & 8 & 8 \\
\hline & & Decreased & 92 & 92 & 92 \\
\hline \multirow[t]{5}{*}{ Wind strength } & Increased & & 96 & 75 & 76 \\
\hline & No change & & 4 & 25 & 24 \\
\hline & & Increased & 96 & 85 & 76 \\
\hline & & No change & 4 & 8 & 24 \\
\hline & & Unsure & 0 & 8 & 0 \\
\hline \multirow[t]{4}{*}{ Heat } & Increased & & 100 & 100 & 88 \\
\hline & No change & & 0 & 0 & 12 \\
\hline & & Increased & 100 & 100 & 88 \\
\hline & & No change & 0 & 0 & 12 \\
\hline \multirow[t]{6}{*}{ Frequency of drought conditions } & Increased & & 96 & 75 & 88 \\
\hline & No change & & 4 & 25 & 12 \\
\hline & Increased & & 81 & 75 & 88 \\
\hline & & No change & 12 & 17 & 12 \\
\hline & & Decreased & 4 & 0 & 0 \\
\hline & & Unsure & 4 & 8 & 0 \\
\hline \multirow[t]{6}{*}{ Frequency of drying of rivers } & Increased & & 92 & 85 & 90 \\
\hline & No change & & 8 & 15 & 6 \\
\hline & Decreased & & 0 & 0 & 4 \\
\hline & & Increased & 85 & 92 & 94 \\
\hline & & No change & 12 & 8 & 6 \\
\hline & & Decreased & 4 & 0 & 0 \\
\hline \multirow{5}{*}{ Frequency of hunger } & Increased & & 92 & 77 & 90 \\
\hline & No change & & 8 & 12 & 10 \\
\hline & & Increased & 88 & 75 & 90 \\
\hline & & No change & 12 & 17 & 10 \\
\hline & & Unsure & 0 & 8 & 0 \\
\hline \multirow[t]{6}{*}{ Incidence of human diseases } & Increased & & 96 & 69 & 84 \\
\hline & No change & & 4 & 31 & 16 \\
\hline & & Increased & 100 & 75 & 74 \\
\hline & & No change & 0 & 8 & 20 \\
\hline & & Decreased & 0 & 0 & 6 \\
\hline & & Unsure & 0 & 17 & 0 \\
\hline \multirow[t]{6}{*}{ Incidence of animal diseases } & Increased & & 73 & 42 & 66 \\
\hline & No change & & 27 & 58 & 32 \\
\hline & Decreased & & 0 & 0 & 2 \\
\hline & & Increased & 64 & 50 & 62 \\
\hline & & No change & 36 & 42 & 34 \\
\hline & & Decreased & 0 & 8 & 4 \\
\hline \multirow{6}{*}{ Incidence of crop diseases } & Increased & & 92 & 83 & 84 \\
\hline & No change & & 8 & 17 & 16 \\
\hline & Increased & & 92 & 62 & 86 \\
\hline & & No change & 4 & 23 & 14 \\
\hline & & Decreased & 0 & 8 & 0 \\
\hline & & Unsure & 4 & 8 & 0 \\
\hline
\end{tabular}

and 2016/17. A major issue is the occurrence of belowaverage rainfall at the beginning of the cropping seasons: for example, 2013/14, 2014/15, and 2016/17. During the 2015/16 cropping season, a very low amount of rainfall was received between October and December, which are critical months in the cropping season. These have implications for the growth of crops, such as delay in planting activities and the establishment of the earlyplanted crops, which are negatively affected. FAO (2015) confirms these findings of high variability in rainfall amounts and distributional patterns during the cropping season. Low soil moisture at the beginning of the 2015/16 cropping season retarded the development of the early-planted crops in the southern African 


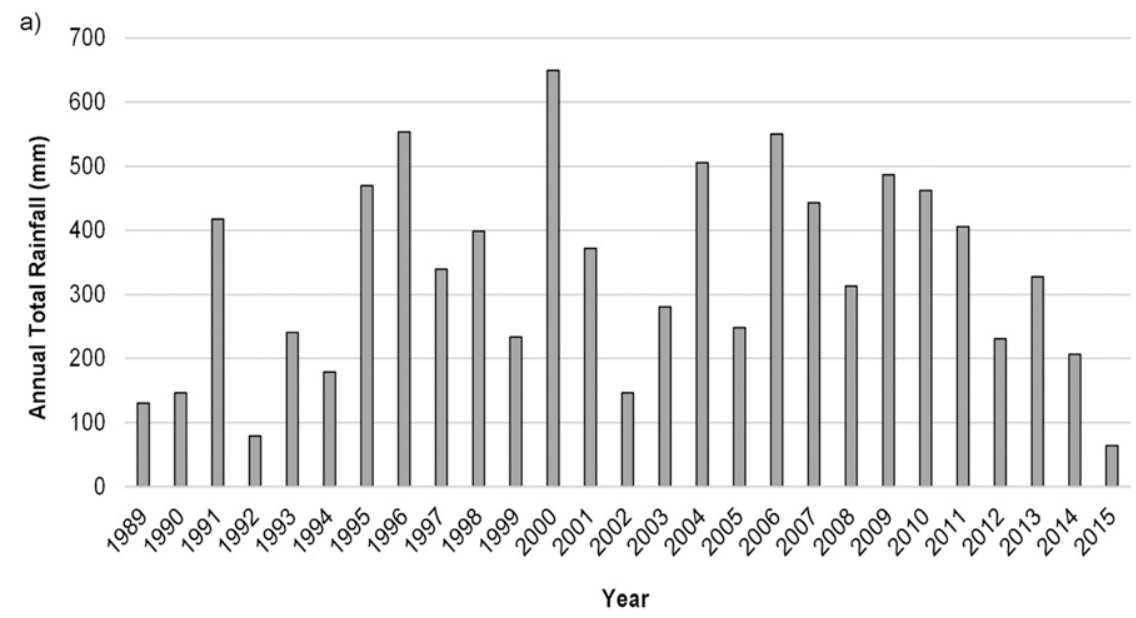

b)

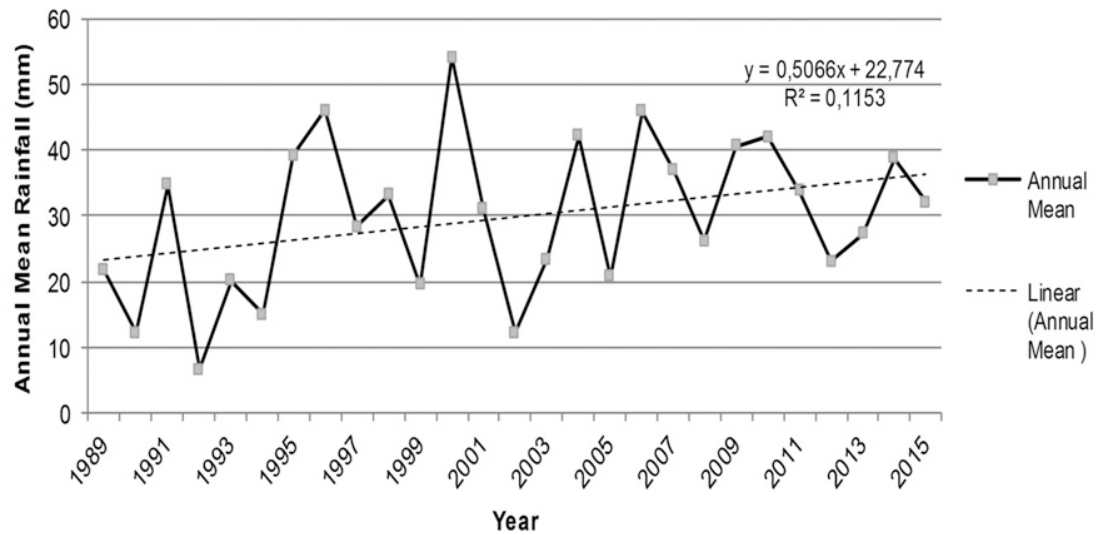

FIG. 4. Rainfall for Palapye police weather station from mid-1989 to February 2015: (a) annual total rainfall and (b) annual mean rainfall (BDSM 2016, personal communication).

region. These are linked to a strong El Niño episode since March 2015, which continued into early 2016, with potential impacts likely to persist well into 2017.

Examining this further for the long term, Fig. $5 \mathrm{c}$ shows rainfall anomalies between 1989 and 2015. The temporal variation of rainfall is considerable, with the year 2000 having above average rainfall. Some of the years with below-average rainfall are 1990, 1992, 1993, 1994, 1999, 2002, 2005, 2012, and 2015. This finding of a temporal variability in rainfall in this region is confirmed by Gbetibouo (2009) and Batisani and Yarnal (2010). Changes in the occurrence of extreme rainfall events may be relevant in this context and should be considered in further investigations.

\section{(ii) Changes in temperature}

All smallholders in the three sublocations perceived rising temperature. However, $12 \%$ of farmers in Lecheng saw no change in heat level both in the short and long term. Probably the cooling effects of the
Tswapong Hills in their vicinity play a role here. It was not possible to compare local perceptions of temperature change with actual weather station data because of the unavailability of temperature records for Palapye. Studies have noted that the effects of water and rainfall reductions on agriculture are exacerbated by increasing temperatures (Müller et al. 2011).

\section{(iii) Occurrence of drought conditions}

Drought in the Botswana context is understood as a deficiency in rainfall in terms of its timing, spatialtemporal distribution, and/or the overall amount received. Its severity relates to the negative impact it has on plant growth, water supply, wildlife, human livelihoods, and food security (World Bank 2010). A majority of farmers; $88 \%$ in Lecheng, $81 \%$ in western Palapye, and $75 \%$ in eastern Palapye, perceived an increase in the frequency of droughts. However, $17 \%$ of farmers from eastern Palapye did not perceive any change in drought frequency in the long term. This could be partly because 
a)

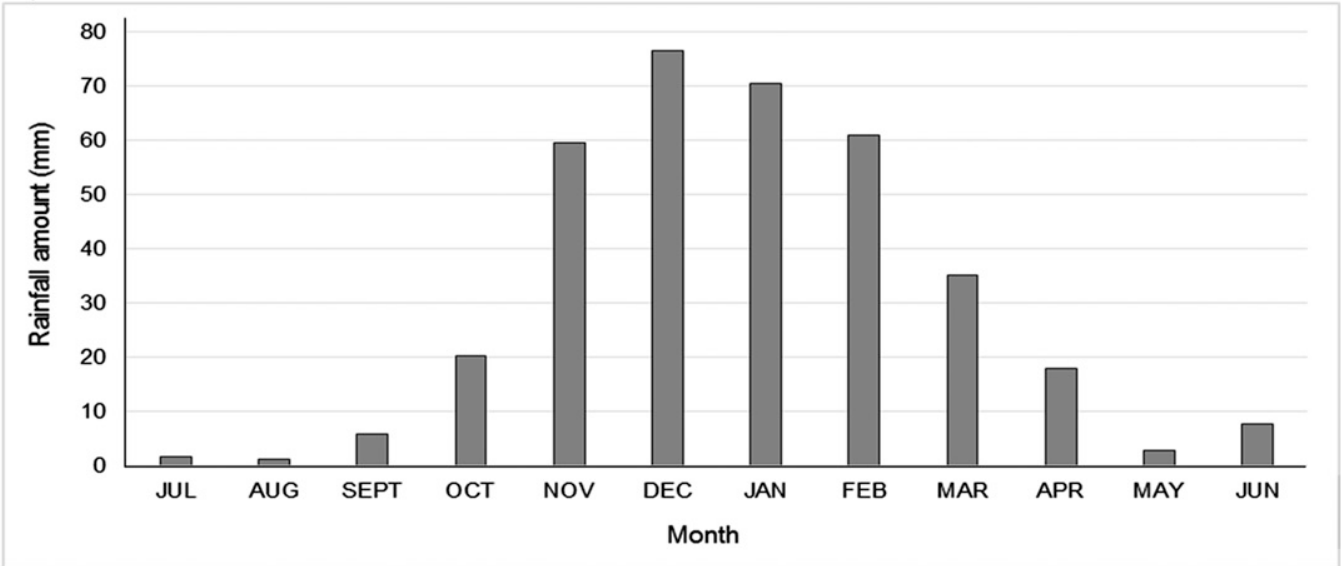

b)

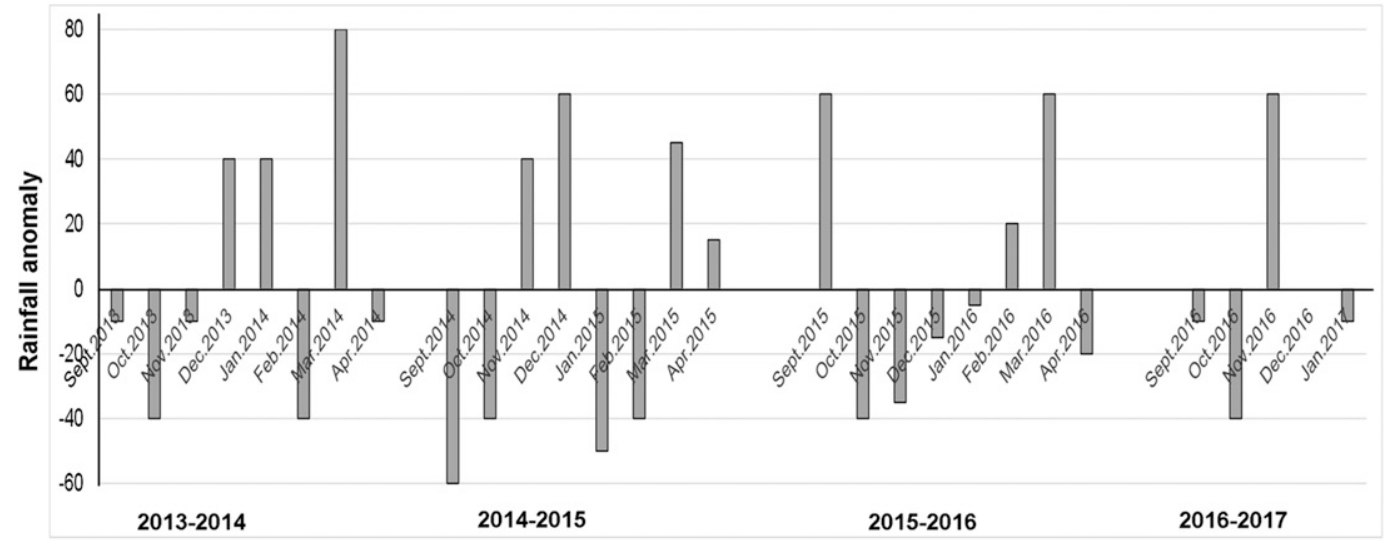

c)

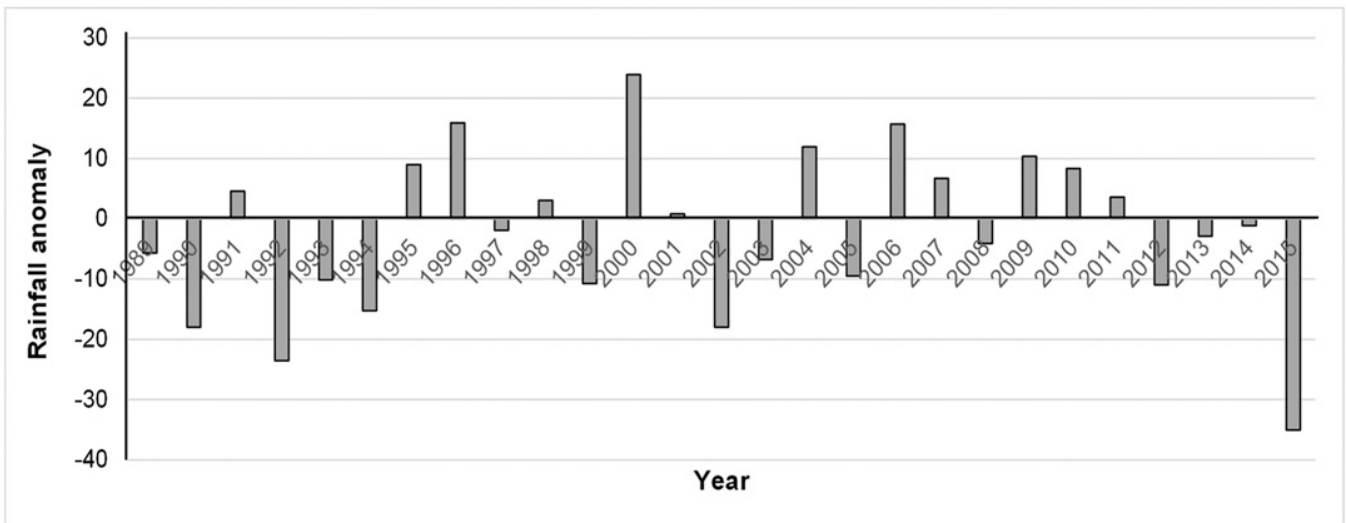

FIG. 5. (a) Monthly rainfall distribution from 1960 to 1990 (BDSM 2016, personal communication). (b) Monthly rainfall anomaly for 2013-17 growing seasons based on ECMWF data (FAO-GIEWS, http://www.fao.org/giews/ earthobservation/country/index.jsp?code5BWA\#). (c) Annual rainfall anomaly for Palapye between 1989 and 2015.

of the availability of water for irrigation and watering of livestock from the Dikabeya Dam in eastern Palapye. Also utilized is treated waste water discharged from the nearby Palapye treatment plant.
SPI results were compared with farmers' perceptions of drought conditions. Figure 6 shows the temporal variation of SPI on a 12-month scale. Palapye experienced a series of moderate/extreme droughts (i.e., SPI $<-1.0$ 


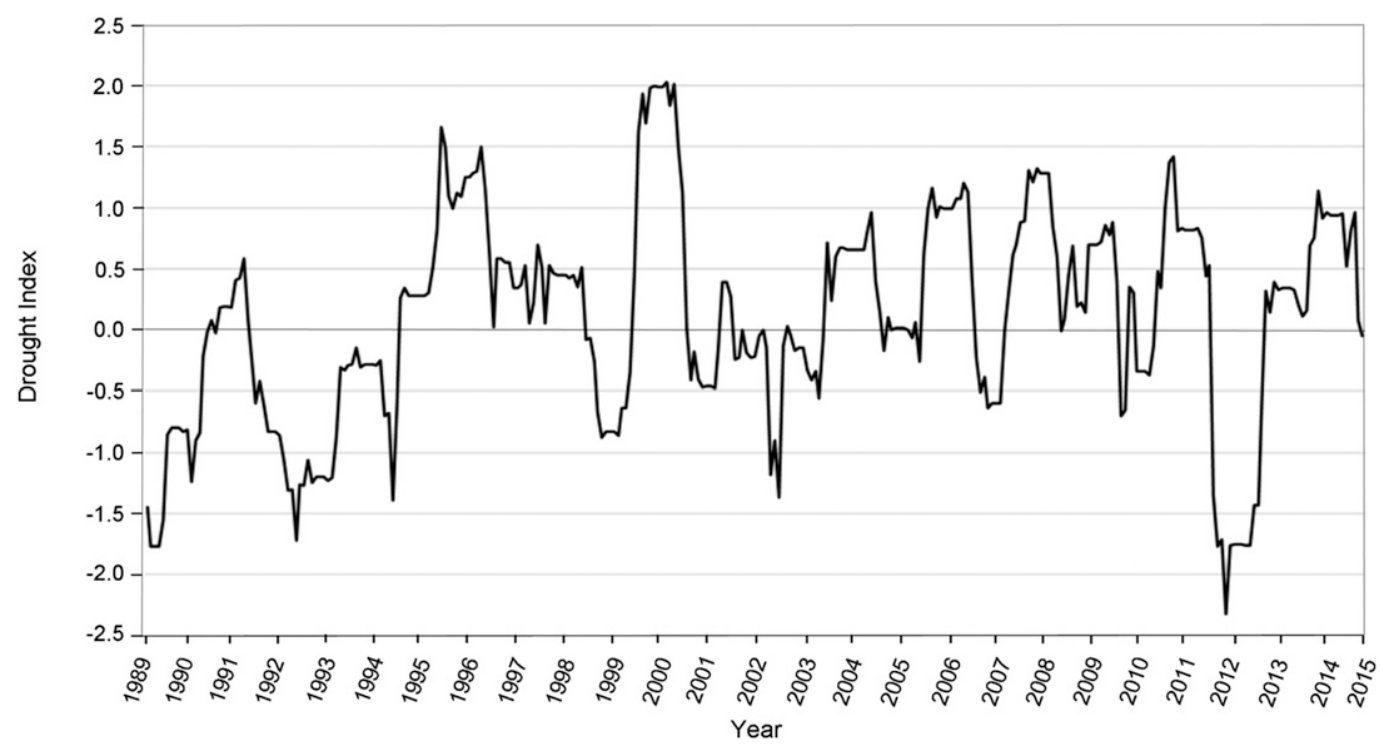

FIG. 6. The interannual variation of the drought index (SPI) for Palapye.

to $<-2.0$ ) between 1989 and 2015. Results show SPI as low as -1.77 (severe drought) in 1990, -1.37 (moderate drought) in 2003, and -2.32 (extreme drought) in 2012. This finding agrees with farmers' perceptions of an increase in drought conditions and severity.

Drought and household food security are assessed annually in Botswana to verify the situation and guide government intervention (World Bank 2010).

\section{d. Climatic factors constraining agricultural production}

Mishra and Singh (2010) noted the need to assess the potential impacts of climate change on agricultural production at various scales. This is in order to develop measures aimed at reducing agricultural vulnerability and securing farmer livelihoods. Cultivators attributed low crop yield mostly to erratic and low rainfall amount, high temperatures, and increase in drought conditions. Pastoralists mentioned low-quality forage for grazing livestock and limited water supply as impacts. To gauge the severity of impacts, farmers' perceptions of severity were measured on a five-point Likert scale with 1 being very severe to 5 being not very severe (Table 4).

For crop production, the most constraining climatic factor is rising temperature, with its impact perceived by the majority $(83 \%)$ as very severe, and $58 \%$ of smallholders perceive the impact of heat waves on crops as very severe. Battisti and Naylor (2009) noted the sensitivity of agricultural production to higher temperatures. Of the farmers, $66 \%$ indicated drought-related constraints on crop production to be very severe, whereas
$18 \%$ perceived it as severe, with only $8 \%$ indicating that the impact is moderately severe. Africa is most susceptible to low yield caused by drought when compared with other regions ( $\mathrm{Li}$ et al. 2009). That drought threatens climate-sensitive economic sectors, such as agriculture, is known (Mishra and Singh 2010). The perceived severity of changing rainfall pattern on crop production is also very severe $(47 \%)$. The negative impact that the changing rainfall pattern has on crop production in Africa is also confirmed by Müller et al. (2011). For livestock production, the most constraining climatic factor is drought, with its impact perceived by the majority $(62 \%)$ as very severe.

Average severity score for each climatic factor per farmer and the proportion of each severity category were

TABLE 4. Severity of climatic factors constraining crop and livestock production: 1) very severe, 2) severe, 3) moderate, 4) not severe, and 5) not very severe.

\begin{tabular}{|c|c|c|c|c|c|c|c|c|c|c|}
\hline \multirow[b]{3}{*}{ Climatic factors } & \multicolumn{10}{|c|}{ Perceived severity among farmers $(\%)$} \\
\hline & \multicolumn{5}{|c|}{ Crops } & \multicolumn{5}{|c|}{ Livestock } \\
\hline & 1 & 2 & 3 & 4 & 5 & 1 & 2 & 3 & 4 & 5 \\
\hline Drought & 66 & 18 & 8 & 1 & 6 & 62 & 13 & 10 & 6 & 9 \\
\hline Flood & 16 & 2 & 6 & 6 & 71 & 15 & 1 & 7 & 4 & 73 \\
\hline Heat wave & 58 & 14 & 18 & 5 & 6 & 24 & 20 & 20 & 5 & 31 \\
\hline Cold wave & 19 & 11 & 22 & 12 & 36 & 10 & 7 & 18 & 10 & 55 \\
\hline High temperature & 83 & 5 & 5 & 2 & 6 & & & & & \\
\hline Off-season rain & 46 & 8 & 15 & 6 & 25 & 23 & 18 & 12 & 4 & 43 \\
\hline Storm & 23 & 6 & 23 & 7 & 40 & 16 & 8 & 12 & 6 & 59 \\
\hline Insects/Diseases & 37 & 16 & 17 & 8 & 22 & & & & & \\
\hline Wild fire & 13 & 5 & 5 & 4 & 74 & & & & & \\
\hline Changing rainfall pattern & 47 & 18 & 10 & 6 & 19 & & & & & \\
\hline
\end{tabular}



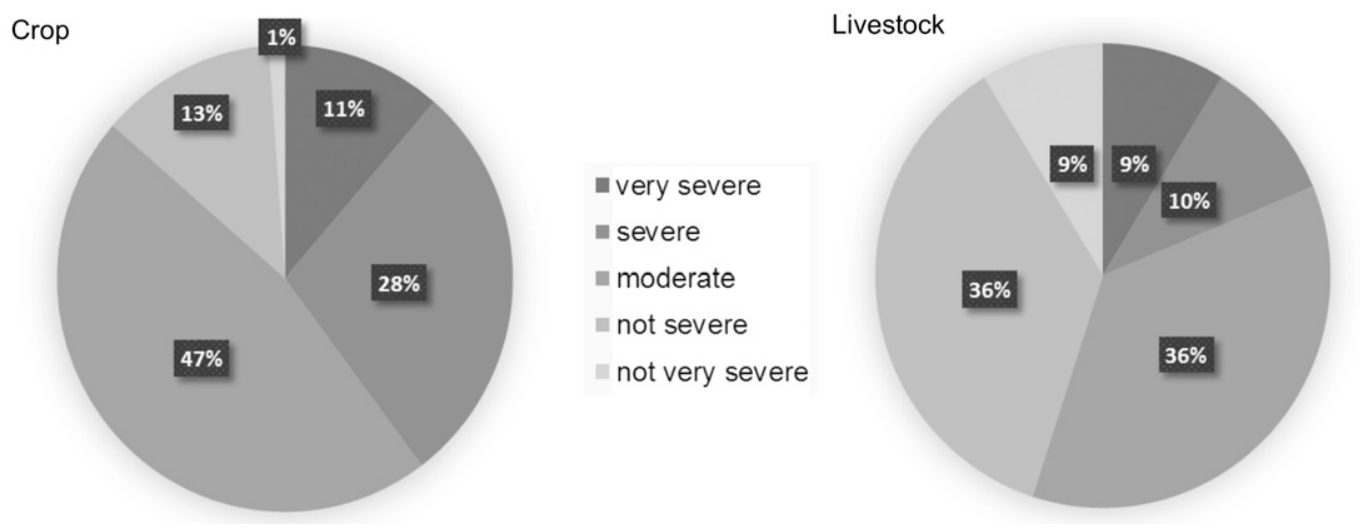

FIG. 7. Severity of the impact of climatic factors on agricultural production.

calculated. Figure 7 shows that $47 \%$ of farmers perceived climatic constraints on crop production to be moderately severe, $28 \%$ perceived it to be severe, and $11 \%$ perceived it as very severe. For livestock production, $36 \%$ perceived the impacts of climatic constraints to be moderate and not severe, respectively, $10 \%$ perceived impacts as severe, and $9 \%$ as very severe. The overall severity rating of all climatic factors constraining crop and livestock production are moderate (severity scale 3 ) and severe (severity scale 2), respectively.

\section{e. Strategies adopted to cope with climate change and variability}

A community's ability to cope with rainfall variability, for example, gives an indication of its adaptive capacity to climate change (Cooper et al. 2008; Shahid et al. 2015; Thaker et al. 2016). African farmers' capacity to adapt in the face of climate change is low (Hassan and Nhemachena 2008; Bunce et al. 2010; Dube et al. 2016). Without sufficient adaptation measures for climate change in southern Africa, staple crops of importance to large food-insecure human populations will likely be negatively affected (Lobell et al. 2008). Farmers generally expressed uncertainties on how to cope. In the words of a farmer from western Palapye, "it is hard to know what to plow or how the weather will be as climate seems unpredictable." Consequently, farmers adopt different strategies, with $42 \%$ practicing mixed cropping (i.e., intercropping) to reduce the risk and impacts of crop failure (Fig. 8a). The belief is that crops are not equally affected by low, erratic rainfall and drier conditions. Farmers' use of mixed cropping is meant to give them alternatives. In their own words, "some crops will survive and some will not. If one crop fails, at least others are harvested and there will be something to eat." Ogalleh et al. (2012) found intercropping to be the most practiced adaptation on most farms in Umande and Muhonia, Kenya. Of those who don't practice intercropping, $28 \%$ of farmers would do nothing, $16 \%$ plant early maturing crops (e.g., hybrid maize provided by the government), $7 \%$ shift to planting other crops, and $4 \%$ plow and pray to God for rain.

Figure $8 \mathrm{~b}$ shows crops that farmers perceive as being most prone to climatic impact. Only $27 \%$ of smallholders grow crops they believe to be less risky to changing climatic conditions. As an adjustment mechanism, farmers shifted from planting maize to beans, sorghum varieties, hybrid maize, cabbage, and watermelon (Fig. 8c). The varieties of beans mostly preferred are mung beans (Vigna radiata) and Tswana beans, which are drought tolerant. Swe et al. (2015) found that farmers perceived the cultivation of droughtresistant plant varieties as a strategy to cope with water scarcity in Myanmar. That farmers plant many crops and varieties simultaneously as a coping strategy is in line with findings from Smit and Wandel (2006) and Ogalleh et al. (2012).

Studies have equally found that moving into a mixed crop-livestock system by farmers is also related to diversification and adaptation (Kurukulasuriya and Mendelsohn 2008; Di Falco 2014). The majority (92\%) of farmers reported agriculture as their main occupation, with $69 \%$ practicing mixed crop-livestock farming. Figure 9 shows coping strategies among livestock farmers. These include supplementary feeding of livestock with grass cut from the roadside, harvested stalks (crop residues) from farmlands, the buying of Lablab purpureus ${ }^{1}$ (lablab), and molasses as feed. Other strategies include destocking to reduce the number of livestock by selling off some during drought and moving livestock to areas with better forage. Some farmers keep livestock in paddocks or

\footnotetext{
${ }^{1}$ When known, the plant's scientific name, common name, and local name (underlined) are given.
} 
a)

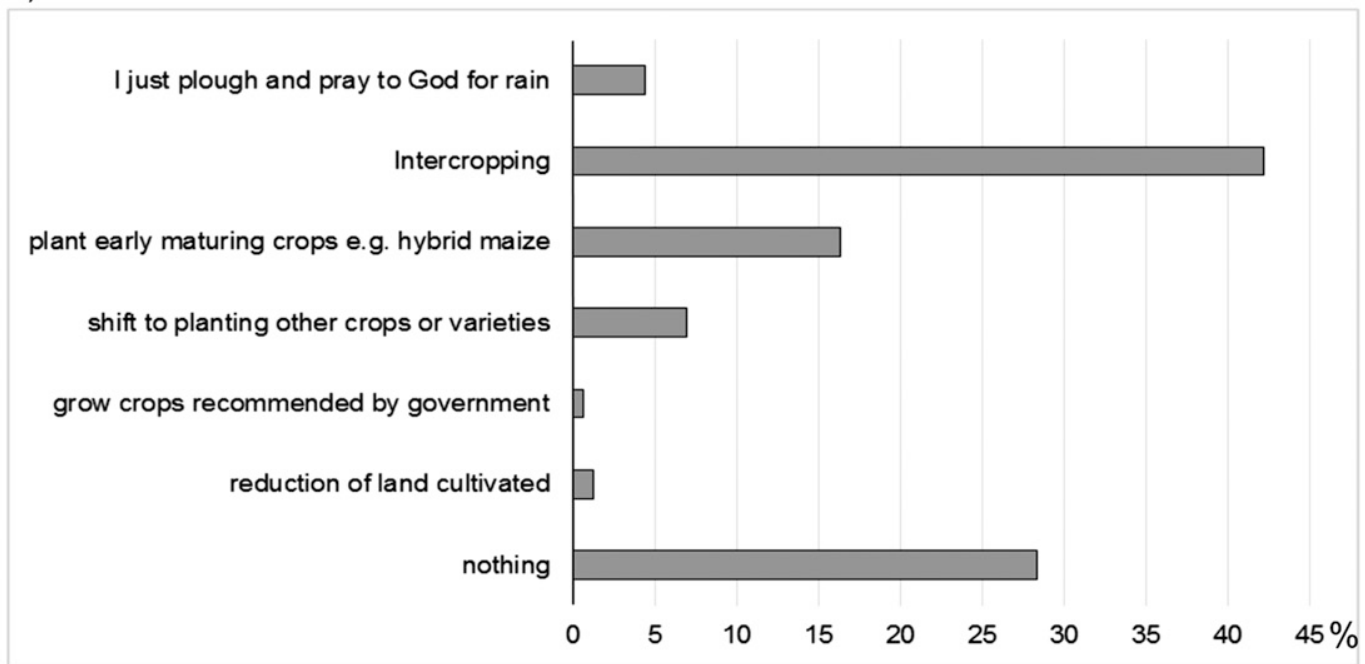

b)

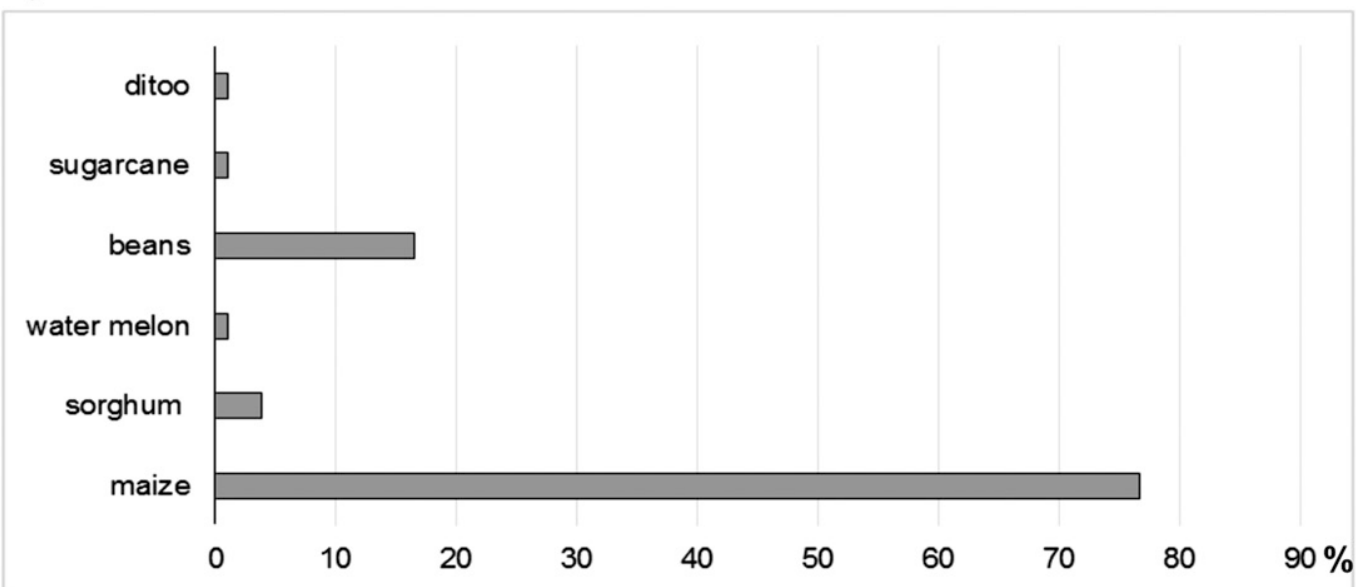

c)

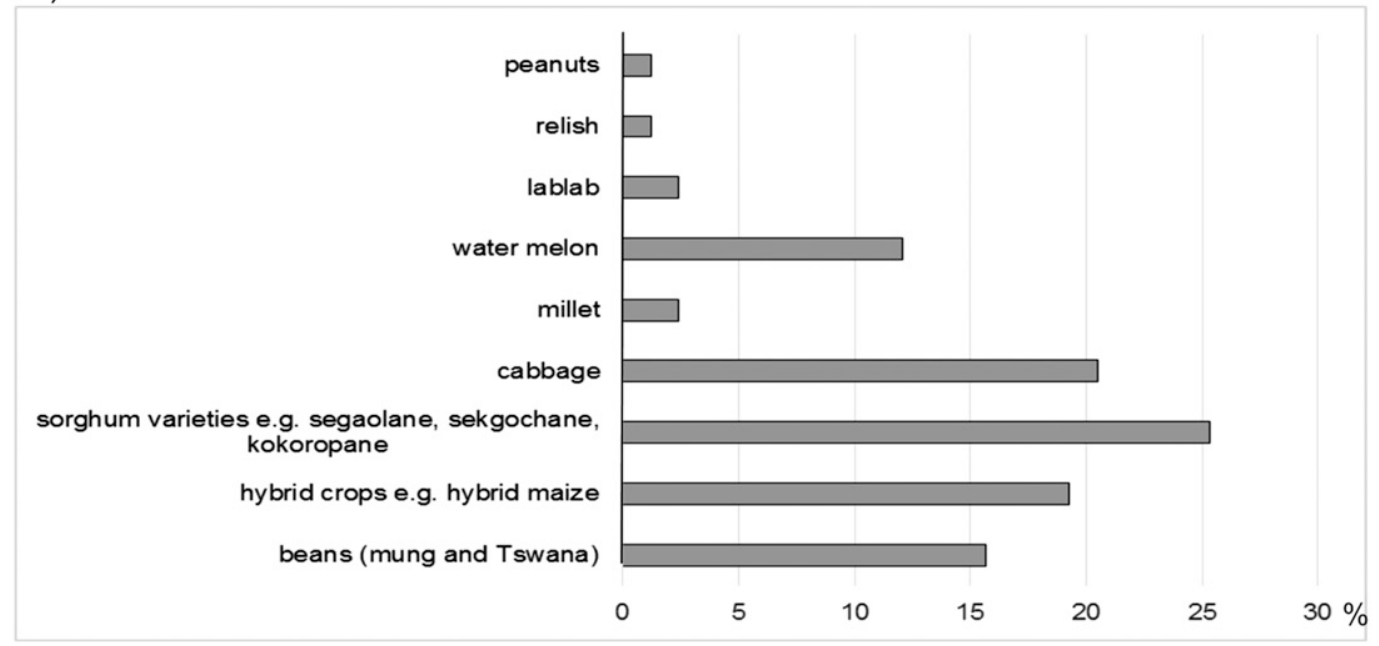

FIG. 8. Adjustment mechanisms to climatic impacts on crop production: (a) strategies adopted by farmers, (b) crops perceived as most prone to impact, and (c) less-risky crops grown. 


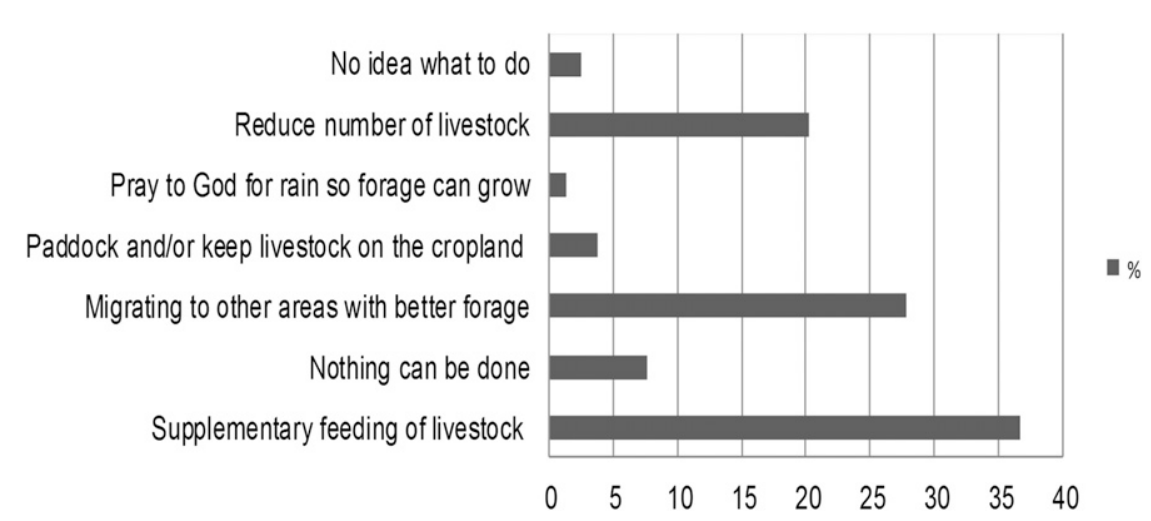

FIG. 9. Strategies adopted by livestock farmers.

allow them to roam free on the cropland (4\%), $8 \%$ feel nothing can be done, $3 \%$ have no idea what to do, and $1 \%$ pray to God for rain. Smallholder farmers, particularly those that do nothing or have no idea what to do, can benefit from improved access to information and extension services.

Augmenting with off-farm incomes is widely reported as a coping strategy among farmers in Palapye. A farmer said, "when there is no rainfall, we do not have anything to eat. We have to divert from farming to other ways of earning money to buy food." Six percent engage in selling veld (bush) products, such as fuelwood, Colophospermum mopane (mopane or mophane) worms, Grewia flava (wild berries or moretlwa), and thatching grass. Those receiving pensions monthly are $3 \%$; another $3 \%$ brew local beer from sorghum; $2 \%$ obtain house rents, whereas $1 \%$ receive remittances from grown-up children; and 1\% are enrolled in Ipelegeng (Botswana's poverty alleviation program). This finding that off-farm incomes augment farm income, which is climate sensitive, is adding empirical evidence to the importance of income diversification as a coping strategy among smallholders, particularly in Africa's drylands. Di Falco (2014) noted that adaptation among African farmers is more effective when it is a combination of measures.

In this study, gender differences in adaptation were not apparent in farmers' responses. Although the disproportionate ratio of male to female farmers sampled could have influenced results, strategies adopted by female farmers, who made up $38 \%$ of the sample, were similarly reported by male farmers. Few studies have examined how gender might influence the choice of strategies adopted to cope and adapt to climate change and variability in Africa. For example, Nhemachena and Hassan (2007) found that female-headed farming households in southern Africa are more likely to adapt to climate change. This is partly attributed to women doing much of the agricultural work in rural communities in Africa as more men migrate to urban areas in search of off-farm jobs. Consequently, women are able to make the decisions (United Nations 2000; Nhemachena and Hassan 2007). However, women's lesser access to critical resources, such as land and finance, low nutrient input mainly as a result of the agriculture poverty trap, insignificant investment in irrigation, and exorbitant transport cost, among other factors, limit agricultural development in Africa (World Bank 2008; Gbetibouo 2009; Storeygard 2012).

Improving agricultural productivity is a major goal in Botswana as the government seeks to diversify the economy (MFDP 2010). Smallholder agriculture and related activities are vital for livelihoods, food security, and national economy (Sonwa et al. 2017). Harnessing existing local knowledge and farmer perceptions of changing climatic conditions are necessary to develop national policies targeting smallholder farmers. For example, farmers' shift to planting crops and varieties that are deemed less risky to climate change and variability requires further government support in promoting such crops. It was observed that most farmers would only plant crops they eat without reasoning that other droughttolerant crops can be grown and sold to generate income [e.g., millet (lebelebe)]. Millet is tolerant of drier conditions and is nutritious for human consumption and for feeding livestock (Saleh et al. 2013). Policies are needed in this regard to better support smallholders in further developing appropriate coping strategies and adaptation measures. Newsham and Thomas (2011) call for climate change adaptation policy engagement with local knowledge systems given the uncertainties inherent in projected impacts of climate change in Africa. If local knowledge held by smallholder farmers in different parts of Africa is not adequately understood, research aimed at enhancing 
their adaptive capacity to climate change impacts will be limited.

\section{Conclusions}

This article examined smallholder farmers' perception of climate change and variability in semiarid Palapye, eastern Botswana. As a first step to enhancing smallholders' adaptive capacity, it is imperative to understand their perceptions, as perception influences how they choose to adapt to changing climatic conditions. Prominent among conditions that are perceived as changing are rainfall amount and timing, temperature, and increasing drought frequency.

Farmers' perceptions were compared to results of climate data analysis. For example, high variability in rainfall amount is evident throughout the rainfall series from 1989 to 2015. Comparison of the records for the last three cropping seasons shows poor rainfall distribution and below-average rainfall at the beginning of the cropping seasons, as evidenced by rainfall anomalies for the study area. Of all climatic factors constraining crop and livestock production, the impact of rising temperature was most severe on crops, whereas increasing frequency of drought conditions resulting in low-quality forage for grazing was most severe on livestock.

Some adaptation strategies were adopted by smallholders to minimize climate-related impacts. Intercropping, referred to as crop mixing, whereby farmers plant several crops and varieties simultaneously, was most widespread. This is done with the belief that all crops are not equally affected by low rainfall and/or drier conditions. Thus, crops that eventually survive guarantee some harvest. As a result of changing climatic conditions, it was observed that the majority of farmers shifted from planting crops such as maize to more drought-resistant crop varieties and early maturing crops, such as sorghum. The majority of smallholders also practice mixed crop-livestock farming in the face of changing climatic conditions. Among livestock farmers, supplementary feeding of livestock, destocking, and moving to areas with better forage are the main strategies adopted when there is drought. This study confirms the importance of off-farm incomes to smallholder farming households as a coping strategy. Identified sources of off-farm incomes are the sale of products from the wild, local beer made from sorghum, and, to a lesser extent, monthly pensions, remittances, and participation in the poverty alleviation program.

This research contributes to efforts in establishing the value of local knowledge for understanding and dealing with climate change empirically. Its findings add to evidence that smallholder farmers take measures, though
TABLE A1. Perception of initial and current climate by sublocations.

\begin{tabular}{llccc}
\hline \hline \multirow{2}{*}{ Indicators } & & \multicolumn{3}{c}{ Palapye sublocations (\%) } \\
\cline { 3 - 5 } & Perception & West & East & Lecheng \\
\hline $\begin{array}{l}\text { Initial climate at } \\
\text { settling }\end{array}$ & Good & 79 & 85 & 94 \\
& & & & \\
\multirow{5}{*}{ Current climate } & Bad & 14 & 0 & 4 \\
& Very bad & 7 & 15 & 2 \\
& Good & 4 & 0 & 2 \\
& Bad & 28 & 31 & 8 \\
& Very bad & 68 & 69 & 90 \\
\hline
\end{tabular}

limited in scope, to cope and reduce impacts from climate change and variability. For example, shifting to planting crops and varieties that are deemed less risky is a proof that local knowledge does exist about climatic impacts on different crops, which informs how farmers choose to cope. Whether these strategies adopted are effective warrants further examination. Evidence-based policy making regarding how future climate change may impact smallholders' livelihoods in Botswana is equally important.

Acknowledgments. Financial support was received to conduct the farmer survey and interviews through the Land Degradation Index Mapping (LDIMapping) project. The project was funded by the U.S. Agency for International Development (USAID) through the RCMRD/SERVIRAfrica Small Grants Program (SERVIR/E\&S/2014/004) and cofunded by the Botswana International University of Science and Technology (BIUST). A research permit was granted by the Government of Botswana. We would like to thank the Palapye Administrative Authority, Palapye Tribal Authority, Palapye farmers' committee chairman and representatives, agricultural demonstrators of the Ministry of Agriculture, Development and Food Security for facilitation and farmers for their time and permission to enter their fields. We are grateful to Dr. Sarah Ogalleh for sharing a questionnaire relating to a Kenyan study. Research and field assistants Margaret Kgomo, who was in-charge of the survey, Ndiye Kebonye, Modise Mhete, Michael Molaodi, Marea Oabonwa, and Masego More are acknowledged. The useful comments of anonymous reviewers are highly appreciated. Any opinions expressed in this article are those of the author and do not reflect those of the funders.

\section{APPENDIX}

Farmers from the three sublocations were asked to rate the state of the climate at the time when they settled and present day. The responses are shown in Table A1. 


\section{REFERENCES}

Adelabu, S., O. Areola, and R. Sebego, 2011: Assessing growing season changes in southern Botswana. Afr. J. Plant Sci. Biotechnol., 5, 81-88.

Akinyemi, F. O., 2011: Evaluating access to spatial data and information in Rwanda. Urban Reg. Inf. Syst. Assoc. J., 23, 39-47.

Ayanlade, A., T. O. Odekunle, O. I. Orinmogunje, and N. O. Adeoye, 2009: Inter-annual climate variability and crop yields anomalies in Middle Belt of Nigeria. Adv. Nat. Appl. Sci., 3, 452-465.

Banerjee, R. R., 2015: Farmers' perception of climate change, impact and adaptation strategies: A case study of four villages in the semi-arid regions of India. Nat. Hazards, 75, 2829-2845, doi:10.1007/s11069-014-1466-z.

Batisani, N., and B. Yarnal, 2010: Rainfall variability and trends in semi-arid Botswana: Implications for climate change adaptation policy. Appl. Geogr., 30, 483-489, doi:10.1016/ j.apgeog.2009.10.007.

Battisti, D. S., and R. L. Naylor, 2009: Historical warnings of future food insecurity with unprecedented seasonal heat. Science, 323, 240-244, doi:10.1126/science.1164363.

Boykoff, M. T., M. B. McNatt, and M. K. Goodman, 2015: Communicating in the Anthropocene: The cultural politics of climate change news coverage around the world. The Routledge Handbook of Environment and Communication, A. Hansen and R. Cox, Eds., Routledge Press, 221-231.

Bresciani, F., and A. Valdés, 2007: Beyond Food Production: The Role of Agriculture in Poverty Reduction. Edward Elgar and FAO, 232 pp.

Bunce, M., S. Rosendo, and K. Brown, 2010: Perceptions of climate change, multiple stressors and livelihoods on marginal African coasts. Environ. Dev. Sustainability, 12, 407-440, doi:10.1007/ s10668-009-9203-6.

Burney, J., and V. Ramanathan, 2014: Recent climate and air pollution impacts on Indian agriculture. Proc. Natl. Acad. Sci. USA, 111, 16 319-16 324, doi:10.1073/pnas.1317275111.

Chavez, E., G. Conway, M. Ghil, and M. Sadler, 2015: An end-toend assessment of extreme weather impacts on food security. Nat. Climate Change, 5, 997-1001, doi:10.1038/nclimate2747.

Chipanshi, A. C., R. Chanda, and O. Totolo, 2003: Vulnerability assessment of the maize and sorghum crops to climate change in Botswana. Climatic Change, 61, 339-360, doi:10.1023/ B:CLIM.0000004551.55871.eb.

Cooper, P. J. M., J. Dimes, K. P. C. Rao, B. Shapiro, B. Shiferaw, and S. Twomlow, 2008: Coping better with current climatic variability in the rain-fed farming systems of sub-Saharan Africa: An essential first step in adapting to future climate change? Agric. Ecosyst. Environ., 126, 24-35, doi:10.1016/j.agee.2008.01.007.

Deepak, K. R., J. S. Gerber, G. K. MacDonald, and P. C. West, 2015: Climate variation explains a third of global crop yield variability. Nat. Commun., 6, 5989, doi:10.1038/ncomms6989.

DFID, 2008: DFID research strategy 2008-2013 working paper series: Sustainable agriculture. 27 pp. [Available online at http://webarchive.nationalarchives.gov.uk/20160818123400/https:// assets.publishing.service.gov.uk/media/57a08b8f40f0b652dd000d4a/ ResearchStrategyWorkingPaperfinal_agriculture_P1.pdf.]

Di Falco, S., 2014: Adaptation to climate change in sub-Saharan agriculture: Assessing the evidence and rethinking the drivers. Eur. Rev. Agric. Econ., 41, 405-430, doi:10.1093/ erae/jbu014.

__ and M. Veronesi, 2013: How can African agriculture adapt to climate change? A counterfactual analysis from Ethiopia. Land Econ., 89, 743-766, doi:10.3368/le.89.4.743.
Drechsel, P., L. Gyiele, D. Kunze, and O. Cofie, 2001: Population density, soil nutrient depletion, and economic growth in subSaharan Africa. Ecol. Econ., 38, 251-258, doi:10.1016/ S0921-8009(01)00167-7.

Dube, T., P. Moyo, M. Ncube, and D. Nyathi, 2016: The impact of climate change on agro-ecological based livelihoods in Africa: A review. J. Sustain. Dev., 9, 256-267, doi:10.5539/jsd.v9n1p256.

Eicken, H., M. Kaufman, I. Krupnik, P. Pulsifer, L. Apangalook, P. Apangalook, W. Weyapuk Jr., and J. Leavitt, 2014: A framework and database for community sea ice observations in a changing Arctic: An Alaskan prototype for multiple users. Polar Geogr., 37, 5-27, doi:10.1080/1088937X.2013.873090.

FAO, 2006: The state of food insecurity in the world 2006. FAO Rep., 44 pp. [Available online at ftp://ftp.fao.org/docrep/fao/ 009/a0750e/a0750e00.pdf.]

_ 2015: Delayed onset of seasonal rains in parts of southern Africa raises serious concern for crop and livestock production in 2016. FAO Special Alert for Southern Africa 336, 6 pp. [Available online at http://www.fao.org/3/a-i5258e.pdf.]

Feola, G., A. M. Lerner, M. Jain, M. J. F. Montefrio, and K. A. Nicholas, 2015: Researching farmer behaviour in climate change adaptation and sustainable agriculture: Lessons learned from five case studies. J. Rural Stud., 39, 74-84, doi:10.1016/ j.jrurstud.2015.03.009.

Gbetibouo, G. A., 2009: Understanding farmers' perceptions and adaptations to climate change and variability: The case of the Limpopo basin, South Africa. International Food Policy Research Institute (IFPRI) Discussion Paper 00849, 36 pp. [Available online at http://www.ifpri.org/sites/default/files/ publications/ifpridp00849.pdf.]

Hassan, R., and C. Nhemachena, 2008: Determinants of African farmers' strategies for adapting to climate change: Multinomial choice analysis. Afr. J. Agric. Resour. Econ., 2, 83-104.

Hertel, T. W., and S. D. Rosch, 2010: Climate change, agriculture, and poverty. Appl. Econ. Perspect. Policy, 32, 355-385, doi:10.1093/ aepp/ppq016.

Honde, G. J., and F. G. Abraha, 2015: Botswana: African economic outlook. African Development Bank Group, Organisation de Coopération et de Développement Économiques, and United Nations Development Programme Rep., 14 pp. [Available online at http://www.africaneconomicoutlook.org/sites/default/ files/2016-05/Botswana_GB_2016_WEB_0.pdf.]

Jones, C. E., K. Kielland, L. D. Hinzman, and W. S. Schneider, 2015: Integrating local knowledge and science: Economic consequences of driftwood harvest in a changing climate. Ecol. Soc., 20, 25, doi:10.5751/ES-07235-200125.

Kisaka, M. O., M. Mucheru-Muna, F. K. Ngetich, J. N. Mugwe, D. Mugendi, and F. Mairura, 2015: Rainfall variability, drought characterization, and efficacy of rainfall data reconstruction: Case of eastern Kenya. Adv. Meteor., 2015, 380404, doi:10.1155/ 2015/380404.

Kurukulasuriya, P., and R. Mendelsohn, 2008: Crop switching as an adaptation strategy to climate change. Afr. J. Agric. Resour. Econ., 2, 105-125.

— change? World Bank Econ. Rev., 20, 367-388, doi:10.1093/ wber/lhl004.

Lam, V. W. Y., W. W. L. Cheung, W. Swartz, and U. R. Sumaila, 2012: Climate change impacts on fisheries in West Africa: Implications for economic, food and nutritional security. Afr. J. Mar. Sci., 34, 103-117, doi:10.2989/1814232X.2012.673294.

Lee, T. M., E. M. Markowitz, P. D. Howe, C. Y. Ko, and A. A. Leiserowitz, 2015: Predictors of public climate change 
awareness and risk perception around the world. Nat. Climate Change, 5, 1014-1020, doi:10.1038/nclimate2728.

Li, Y. P., W. Ye, M. Wang, and X. D. Yan, 2009: Climate change and drought: A risk assessment of crop-yield impacts. Climate Res., 39, 31-46, doi:10.3354/cr00797.

Lobell, D. B., M. B. Burke, C. Tebaldi, M. D. Mastrandrea, W. P. Falcon, and R. L. Naylor, 2008: Prioritizing climate change adaptation needs for food security in 2030. Science, 319, 607 610, doi:10.1126/science.1152339.

—, W. Schlenker, and J. Costa-Roberts, 2011: Climate trends and global crop production since 1980. Science, 333, 616-620, doi:10.1126/science.1204531.

Lorenzoni, I., S. Nicholson-Cole, and L. Whitmarsh, 2007: Barriers perceived to engaging with climate change among the UK public and their policy implications. Global Environ. Change, 17, 445-459, doi:10.1016/j.gloenvcha.2007.01.004.

Maddison, D. J., 2007: The perception of and adaptation to climate change in Africa. World Bank Policy Research Working Paper 4308, 53 pp. [Available online at http://ssrn.com/ abstract $=1005547$.]

Mashame, G., and F. O. Akinyemi, 2016: Towards a remote sensing based assessment of land susceptibility to degradation: Examining seasonal variation in land use-land cover for modelling land degradation in a semi-arid context. ISPRS Ann. Photogramm. Remote Sens. Spat. Inf. Sci., 3, 137-144.

Mattee, A. Z., K. R. Mussa, D. L. Mwaseba, C. P. Mahonge, and J. V. Nsenga, 2014: Factors in smallholder farmers' vulnerability to climate change impacts in the Uluguru Mountains, Morogoro, Tanzania. Sustainable Intensification to Advance Food Security and Enhance Climate Resilience in Africa, R. Lal et al., Eds., Springer, 185-200, doi:10.1007/978-3-319-09360-4_9.

Mengistie, B. T., A. P. Mol, and P. Oosterveer, 2015: Pesticide use practices among smallholder vegetable farmers in Ethiopian Central Rift Valley. Environ. Dev. Sustain., 19, 301-324, doi:10.1007/s10668-015-9728-9.

Mertz, O., C. Mbow, A. Reenberg, and A. Diouf, 2009: Farmers' perceptions of climate change and agricultural adaptation strategies in rural Sahel. Environ. Manage., 43, 804-816, doi:10.1007/s00267-008-9197-0.

MFDP, 2010: 10th national development plan (2009-2016) for Botswana. MFDP Rep., 391 pp. [Available online at http:// www.nationalplanningcycles.org/sites/default/files/country_ docs/Botswana/ndp_botswana.pdf.]

Mishra, A. K., and V. P. Singh, 2010: A review of drought concepts. J. Hydrol., 391, 202-216, doi:10.1016/j.jhydrol.2010.07.012.

Müller, C., W. Cramer, W. L. Hare, and H. Lotze-Campen, 2011: Climate change risks for African agriculture. Proc. Natl. Acad. Sci. USA, 108, 4313-4315, doi:10.1073/pnas.1015078108.

Newsham, A. J., and D. S. G. Thomas, 2011: Knowing, farming and climate change adaptation in north-central Namibia. Global Environ. Change, 21, 761-770, doi:10.1016/j.gloenvcha.2010.12.003.

Nhemachena, C., and R. Hassan, 2007: Micro-level analysis of farmers' adaptation to climate change in southern Africa. International Food Policy Research Institute Discussion Paper 00714, 30 pp.

Ogalleh, S. A., R. V. Christian, J. Eitzinger, and M. Hauser, 2012: Local perceptions and responses to climate change and variability: The case of Laikipia District, Kenya. Sustainability, 4, 3302-3325, doi:10.3390/su4123302.

Osbahr, H., C. Twyman, W. N. Adger, and D. S. G. Thomas, 2010: Evaluating successful livelihood adaptation to climate variability and change in southern Africa. Ecol. Soc., 15, 27, doi:10.5751/ES-03388-150227.
Osborne, T. M., and T. R. Wheeler, 2013: Evidence for a climate signal in trends of global crop yield variability over the past 50 years. Environ. Res. Lett., 8, 024001, doi:10.1088/1748-9326/8/ 2/024001.

Parida, B. P., and D. B. Moalafhi, 2008: Regional rainfall frequency analysis for Botswana using L-Moments and radial basis function network. Phys. Chem. Earth, 33, 614-620, doi:10.1016 j.pce.2008.06.011.

Parry, M. L., and Coauthors, 2001: Millions at risk: Defining critical climate change threats and targets. Global Environ. Change, 11, 181-183, doi:10.1016/S0959-3780(01)00011-5.

Parson, J., 1984: The peasantariat and politics: Migration, wage labor, and agriculture in Botswana. Afr. Today, 31, 5-25.

Phalkey, R. K., C. Aranda-Jan, S. Marx, B. Höfle, and R. Sauerborn, 2015: Systematic review of current efforts to quantify the impacts of climate change on undernutrition. Proc. Natl. Acad. Sci. USA, 112, E4522-E4529, doi:10.1073/pnas.1409769112.

Rippke, U., and Coauthors, 2016: Timescales of transformational climate change adaptation in sub-Saharan African agriculture. Nat. Climate Change, 6, 605-609, doi:10.1038/nclimate2947.

Saleh, A. S. M., Q. Zhang, J. Chen, and Q. Shen, 2013: Millet grains: Nutritional quality, processing, and potential health benefits. Compr. Rev. Food Sci. Food Saf., 12, 281-295, doi:10.1111/ 1541-4337.12012.

Shahid, S., X. J. Wang, S. B. Harun, S. B. Shamsudin, T. Ismail, and A. Minhans, 2015: Climate variability and changes in the major cities of Bangladesh: Observations, possible impacts and adaptation. Reg. Environ. Change, 16, 459-471, doi:10.1007/ s10113-015-0757-6.

Smit, B., and J. Wandel, 2006: Adaptation, adaptive capacity, and vulnerability. Global Environ. Change, 16, 282-292, doi:10.1016/ j.gloenvcha.2006.03.008

Sonwa, D. J., and Coauthors, 2017: Drivers of climate risk in African agriculture. Climate Dev., doi:10.1080/ 17565529.2016.1167659, in press.

Soussana, J. F., A. I. Graux, and F. N. Tubiello, 2010: Improving the use of modelling for projections of climate change impacts on crops and pastures. J. Exp. Bot., 61, 2217-2228, doi:10.1093/ jxb/erq100.

Statistics Botswana, 2015a: Annual agricultural survey report 2013. Statistics Botswana Rep., 183 pp. [Available online at http://www.statsbots.org.bw/sites/default/files/publications/ agricreport2013.pdf.]

_ 2015b: Serowe/Palapye sub-district population and housing census 2011: Selected indicators. Statistics Botswana Rep., 37 pp. [Available online at http://www.statsbots.org.bw/sites/ default/files/documents/Publication \%2520Catalogue.pdf.]

Storeygard, A., 2012: Farther on down the road: Transport costs, trade and urban growth in sub-Saharan Africa. World Bank Policy Research Working Paper 6444, 55 pp. [Available online at http:// documents.worldbank.org/curated/en/941891467990382913/ pdf/wps6444.pdf.]

Swe, L. M. M., R. P. Shrestha, T. Ebbers, and D. Jourdain, 2015: Farmers' perception of and adaptation to climate-change impacts in the dry zone of Myanmar. Climate Dev., 7, 437-453, doi:10.1080/17565529.2014.989188.

Thaker, J., E. Maibach, A. Leiserowitz, X. Zhao, and P. Howe, 2016: The role of collective efficacy in climate change adaptation in India. Wea. Climate Soc., 8, 21-34, doi:10.1175/ WCAS-D-14-00037.1.

Thomas, A. D., S. R. Hoon, and P. E. Linton, 2008: Carbon dioxide fluxes from cyanobacteria crusted soils in the Kalahari. Appl. Soil Ecol., 39, 254-263, doi:10.1016/j.apsoil.2007.12.015. 
Thomas, D. S. G., C. Twyman, H. Osbahr, and B. Hewitson, 2007: Adaptation to climate change and variability: Farmer responses to intra-seasonal precipitation trends in South Africa. Climatic Change, 83, 301-322, doi:10.1007/s10584-006-9205-4.

Thornton, P. K., R. B. Boone, and J. Ramirez-Villegas, 2015: Climate change impacts on livestock. CGIAR Research Program on Climate Change, Agriculture and Food Security Working Paper 120, 21 pp. [Available online at www.ccafs.cgiar.org.]

Torquebiau, E., J. Tissier, and J. V. Grosclaude, 2016: How climate change reshuffles the cards for agriculture. Climate Change and Agriculture Worldwide, E. Torquebiau, Ed., Springer, 1-16, doi:10.1007/978-94-017-7462-8_1.

United Nations, 2000: The World's Women 2000: Trends and Statistics. United Nations Publications, 200 pp.

Van Wesenbeeck, C. F. A., B. G. J. S. Sonneveld, and R. L. Voortman, 2016: Localization and characterization of populations vulnerable to climate change: Two case studies in Sub-Saharan Africa. Appl. Geogr., 66, 81-91, doi:10.1016/ j.apgeog.2015.11.001.

Van Wilgen, N. J., V. Goodall, S. Holness, S. L. Chown, and M. A. McGeoch, 2015: Rising temperatures and changing rainfall patterns in South Africa's national parks. Int. J. Climatol., 36, 706-721, doi:10.1002/joc.4377.
Villoria, N. B., J. Elliott, C. Müller, J. Shin, L. Zhao, and C. Song, 2016: Rapid aggregation of global gridded crop model outputs to facilitate cross-disciplinary analysis of climate change impacts in agriculture. Environ. Modell. Software, 75, 193-201, doi:10.1016/j.envsoft.2015.10.016.

Vision 2016 Council, 2010: Status at glance across all pillars by key results areas. Vision 2016 Council. [Available online at http:// www.vision2016.co.bw/vision-content.php?vid $=30$.]

Wheeler, T., and J. von Braun, 2013: Climate change impacts on global food security. Science, 341, 508-513, doi:10.1126/ science.1239402.

Whitmarsh, L., 2011: Skepticism and uncertainty about climate change: Dimensions, determinants and change over time. Global Environ. Change, 21, 690-700, doi:10.1016/ j.gloenvcha.2011.01.016.

World Bank, 2008: World Development Report 2008: Agriculture for Development. World Bank, 386 pp. [Available online at https:// siteresources.worldbank.org/INTWDR2008/Resources/WDR_ 00_book.pdf.]

, 2010: Botswana climate variability and change: Understanding the risks. Draft Policy Note, $55 \mathrm{pp}$. [Available online at https://www.car.org.bw/wp-content/uploads/2016/06/ Botswana-Climate-Change-Policy-Note.pdf.] 